\title{
The First Record and Origin of Salmo trutta Populations Established in the Upper Tigris River and Lake Van Basin (Teleostei: Salmonidae)
}

\author{
Cüneyt KAYA \\ Recep Tayyip Erdogan University, Faculty of Fisheries, 53100, Rize; Türkiye.
}

How to cite: Kaya, C. (2020). The First Record and Origin of Salmo trutta Populations Established in the Upper Tigris River and Lake Van Basin (Teleostei: Salmonidae). J. Anatolian Env. and Anim. Sciences, 5(3), 366-372.

Atıf yapmak için: Kaya, C. (2020). Yukarı Dicle Nehri ve Van Gölü Havzalarına Yerleşen Salmo trutta Popülasyonlarının İlk Kaydı ve Kökeni (Teleostei: Salmonidae). Anadolu Çev. ve Hay. Dergisi, 5(3), 366-372.

*iD): https://orcid.org/0000-0002-4531-798X

*Corresponding author's:

Cüneyt KAYA

Recep Tayyip Erdogan University, Faculty of Fisheries, 53100, Rize; Türkiye.

\: cuneyt.kaya@erdogan.edu.tr

Mobile telephone : +90 (537) 5104458

Telephone $\quad:+90(464) 2233385$

Fax : +90 (464) 2234118

\begin{abstract}
In the scope of this study, the origin of the two Salmo populations from streams Sapur (southwestern drainage of Lake Van) and Arpet (an uppermost drainage of Botan River, Tigris catchment) was investigated based on morphologic and molecular data. The occurrence of any Salmo species in the mentioned streams has never been recorded up to date. The both populations found conspecific and identified as Salmo trutta which translocated from Europe. Besides, both populations were observed as successfully established.
\end{abstract}

Keywords: Freshwater fish, Eastern Anatolia, first record, trout, exotic.

\section{Yukarı Dicle Nehri ve Van Gölü Havzalarına Yerleşen Salmo trutta (Teleostei: Salmonidae) Popülasyonlarının İlk Kaydı ve Kökeni}

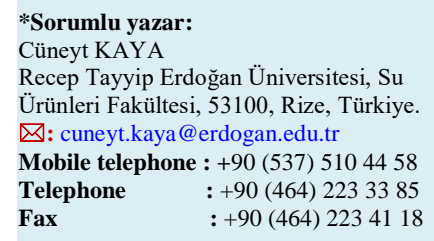

\begin{abstract}
Öz: Bu çalışma kapsamında, Sapur Çayı (Güneybatı Van Gölü drenajı) ve Arpet Çayı'ndan (Botan Irmağı, Yukarı Dicle Nehri) iki Salmo popülasyonunun kökeni morfolojik ve moleküler verilere dayalı olarak araştırılmıştır. Bahsi geçen akarsularda günümüze kadar Salmo cinsine ait herhangi bir türün varlığı bildirilmemiştir. Her iki popülasyonun türdeş ve Avrupa'dan taşınmış olan Salmo trutta'ya ait olduğu saptanmış, sözü geçen iki popülasyonun da akarsu habitatlarına başarılı bir şekilde yerleşmiş olduğu tespit edilmiştir.
\end{abstract}

$\underline{\text { Anahtar kelimeler: Tatlısu balığı, Doğu Anadolu, yeni kayıt, alabalık, egzotik. }}$

\section{INTRODUCTION}

Salmo trutta is distributed from Iceland, Norway, Great Britain, Scandinavia to Chosha Bay (Russia), as well as native to upper Danube and Volga drainages. Likewise, it was introduced throughout Europe, North and South America, southern and eastern montane Africa, India, Pakistan, Nepal, Japan, Australia, and New Zealand (Freyhof, 2011).

Many misidentified or unidentified trout populations in Turkey were recorded as Salmo trutta or its subspecies (S. trutta macrostigma, S. trutta caspius, S. trutta labrax, S. trutta abanticus) until the last decade (Geldiay \& Balık, 1999; Arıman \& Kocaman, 2003; Sarı et al., 2006). However, remarkable taxonomic studies conducted in the last decade by Turan et al. (2010; 2011; 2012; 2014a; 2014b; 2017 ; 2020) which contributed to the clear the taxonomy of genus Salmo in Anatolia, and demonstrated the absence of the $S$. trutta in Turkey.

The occurrence of any Salmo specimen had not been recorded in Lake Van basin and upper Tigris River, except for $S$. tigridis which is known in the streams Çatak 
and Müküs, in eastern drainages of Botan River (Turan et al., 2011; Kaya et al., 2016).

The aim of this study is (i) determine the origin of the Salmo trutta populations found in upper Tigris River and Lake Van drainages, and (ii) reveal whether these populations are established or not.

\section{MATERIAL AND METHOD}

Stream Gökyokuş (mostly known as stream Sapur), located in the south of Tatvan (Bitlis), originates from a spring in the south of Güreş̧̧i and flows toward to Tatvan, then drains to Lake Van (Figure 1a-d). It usually flows slowly or moderately with the stone and gravel substrate. The length of the stream is about $13 \mathrm{~km}$ and the average width of the stream is about 3-4 meters. Stream Kocaçay (mostly known as stream Arpet) originates around Kokarsu and drains to Stream Kezer at $11 \mathrm{~km}$ north of Siirt Province (Figure 1e-f). It usually flows moderately, however, the uppermost part of the stream flows very slowly with meanders. The substrate is with stone and gravel, except for slowly flowing parts which have a sandy substrate. The length of the stream is about $70 \mathrm{~km}$ and the average width of the stream is about 3-4 meters.

Fish samples were caught by pulsed DC electrofishing equipment during June 2018 and October 2019. After anesthesia, some of the samples were fixed in $4 \%$ formaldehyde and transferred to the laboratory for morphological investigation, the others released back to the water. The examined materials deposited in FFR, Recep Tayyip Erdogan University Zoology Museum of the Faculty of Fisheries, Rize; FSJF, Fischsammlung J. Freyhof, Berlin.

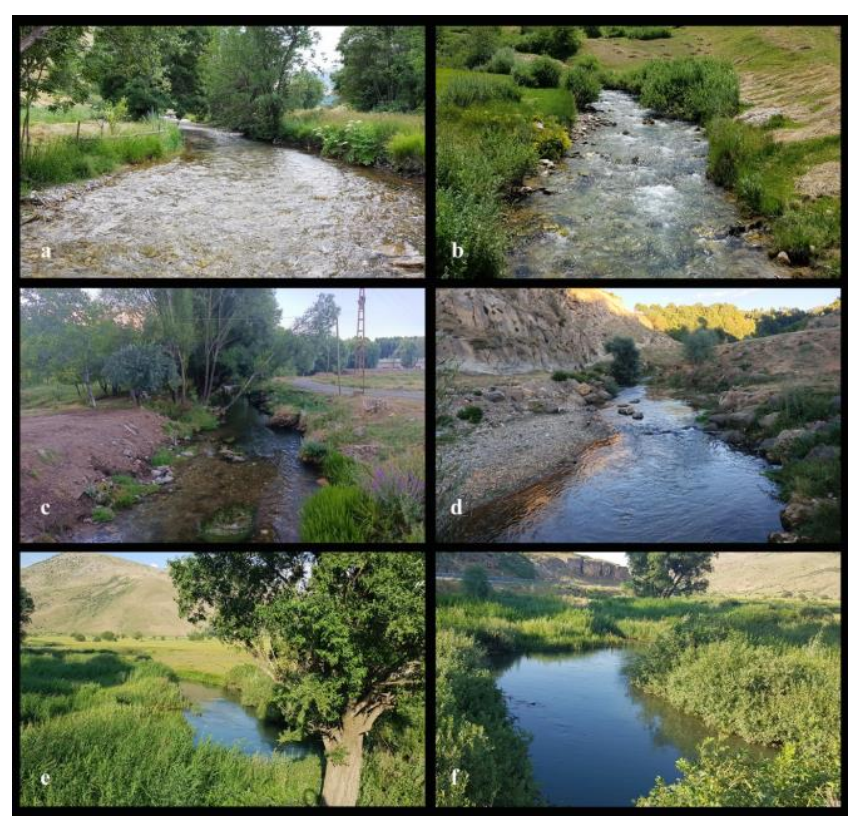

Figure 1. View of the sampling sites: a-b, upper stream Sapur; c-d, lower stream Sapur; e-f, stream Arpet.
DNA Extraction, PCR Amplification, and Sequencing: Genomic DNA was extracted from fin tissues using the DNeasy Blood \& Tissue Kit (Qiagen, Hilden, Germany) on the QIAcube robot (QIAGEN, Valencia, CA). The cytochrome $b$ gene (Cyt $b$ ) of vertebrate mitochondrial DNA was amplified using forward primer SsaL14437 (5'GCTAATGACGCACTAGTCG-3'; Warheit \& Bowman, 2008) and StrCBR (5'- GGGGGCGAGRACTAGGAAGAT -3'; Turan et al., 2011). PCR reactions and amplification conditions were carried out as given in Turan et al. (2020). PCR products were purified using the QIAquick PCR Purification Kit (Qiagen) according to the manufacturer's instructions and bidirectional sequencing of PCR products was performed with an ABI PRISM 3730x1 Genetic Analyser (Applied Biosystem; www. appliedbiosystems.com) using a BigDye Terminator 3.1 cycle sequencing ready reaction kit (Applied Biosystem) at Macrogen Europe (www. macrogen.com).

Genetic Analysis: All Cyt $b$ raw data sequences were aligned with the Clustal W method (Thompson et al., 1994) implemented in Bioedit 7.2.5 (Hall, 1999). Then sequences were trimmed at both ends of forward and reverse and converted to Fasta formatted files. The Cyt $b$ sequences of Salmo trutta were analyzed via BLAST (Basic Local Alignment Search Tool) searches at the NCBI website (http://www.ncbi.nih.gov). Phylogenetic relationships among Salmo species (in this study and from GenBank sequences) were estimated using maximum likelihood (ML) algorithm in MEGA X software (Kumar et al., 2018). The evolution model was selected with the lowest Akaike Information Criterion (AIC) score in MEGA X software (Kumar et al., 2018). ML tree was generated according to the TN93+G model (Tamura and Nei, 1993) that the most appropriate evolution model. ML tree was generated using 1000 bootstrap replicates to explore phylogenetic affinities of the mitochondrial lineages. For phylogenetic analyses, Salmo salar (GenBank Accession number: JX960834; Crête-Lafrenière et al., 2012), Salmo obtusirostris (GenBank Accession number: JX960841; Crête-Lafrenière et al., 2012) and Salmo ohridanus (GenBank Accession number: AF053590; Phillips et al., 2000) from Salmonidae family were used as outgroup.

\section{RESULTS}

A single frozen trout specimen (about $200 \mathrm{~mm} \mathrm{SL}$ ) was examined which was caught by a villager (Muammer Demir) in a very small and shallow irrigation canal (a drainage of Lake Van basin) in the first kilometers of the road between Tatvan and Van $(38.4704,42.3153)$. He claimed that the fish was alive when he caught it. Therefore, I decided to track down the story of the fish and to understand whether this claim is true. Because, up to date, 
there was no record of genus Salmo in the Lake Van basin (Elp et al., 2016). The first examination was demonstrated that the specimen belongs to the genus Salmo. Therefore, a survey was conducted in the closest stream (stream Sapur) in the area (Figure 2) and some Salmo specimens were obtained.

On the other hand, the villagers claimed that there are trouts also in stream Arpet, a northern drainage of Botan River (very close drainage to the stream Sapur). Later, I obtained some Salmo specimens from the stream Arpet also. There was not any Salmo record also from Tigris drainages in the area, except $S$. tigridis which is known in the streams Çatak and Müküs, in eastern drainages of Botan River (Turan et al., 2011; Kaya et al., 2016). However, the natural distribution range of $S$. tigridis is remaining about $80 \mathrm{~km}$ southeast of the stream Arpet.
After these surprise findings in the area, based on both morphological and molecular data it was concluded that the Salmo populations of streams Sapur and Arpet are conspecific, and belong to Salmo trutta.

For molecular analysis, it was sequenced the partial Cyt $b$ from nine individuals belonging to Salmo trutta in Turkey (streams Sapur and Arpet populations). Approximately, 993 bp was amplified from the Cyt $b$ gene. Genbank samples were also included in the genetic analysis. To identify Salmo trutta, the Cyt $b$ sequences were aligned in using GenBank BLAST. The sequences obtained individuals from streams Sapur and Arpet matched to the Salmo trutta specimens from France with a similarity ratio of over $99 \%$. The phylogenetic tree also revealed that the Salmo trutta from Turkey clustered together with those identified from France (Figure 2).

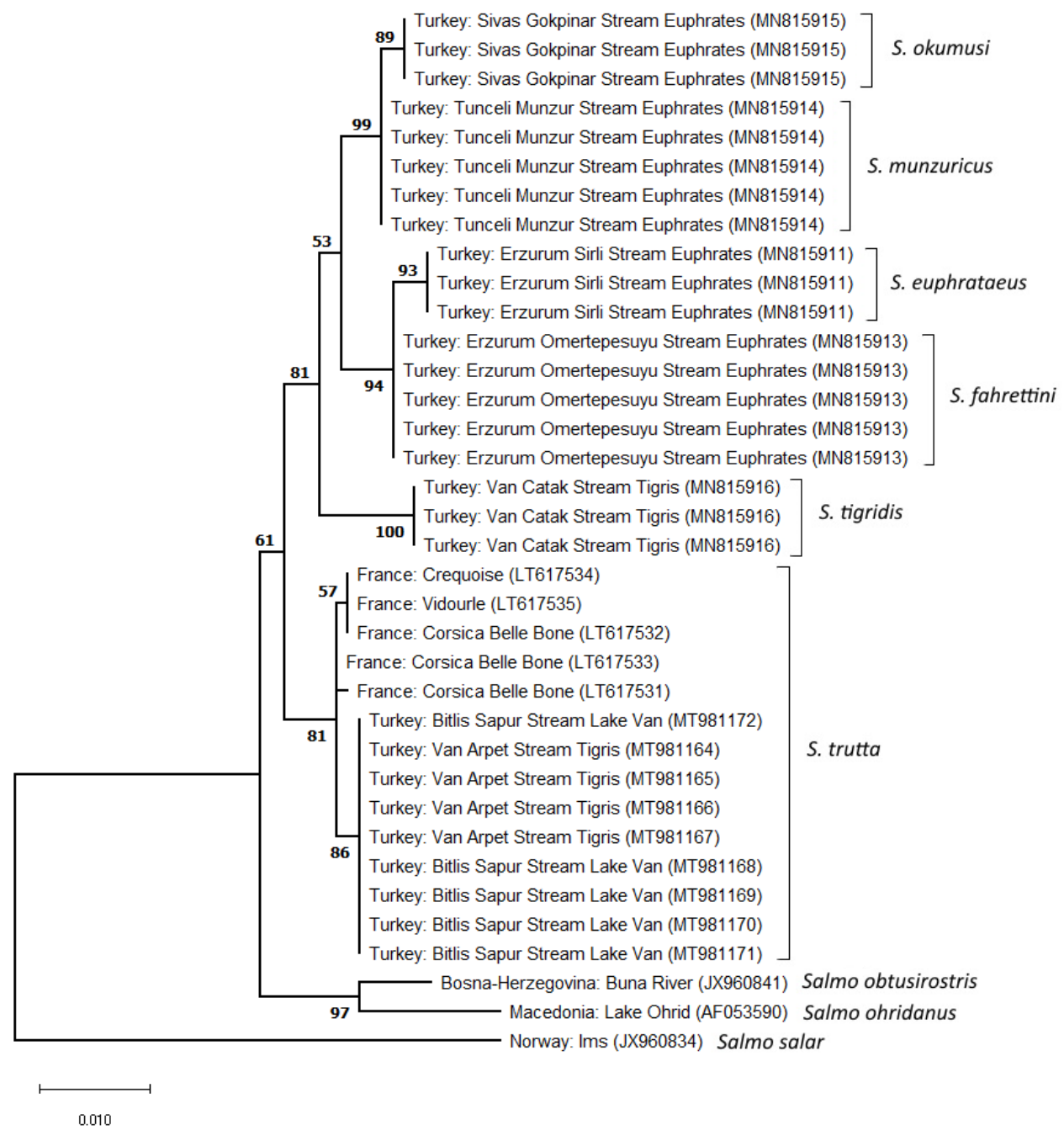

Figure 2. Maximum likelihood (ML) tree based on Cyt $b$ sequences of Salmo trutta and other species in Tigris-Euphrates catchment. Bootstrap and posterior probability values are shown above nodes.

For morphological comparison, the individuals were obtained from streams Sapur and Arpet (Figure 3-4) compared with Salmo trutta from Germany (Figure 5) where the species naturally occurs. Diagnostic features such as body color and pattern, shape and number of the black and red spots on the body, and the shape and size of the adipose-fin and maxillary overlapped. 


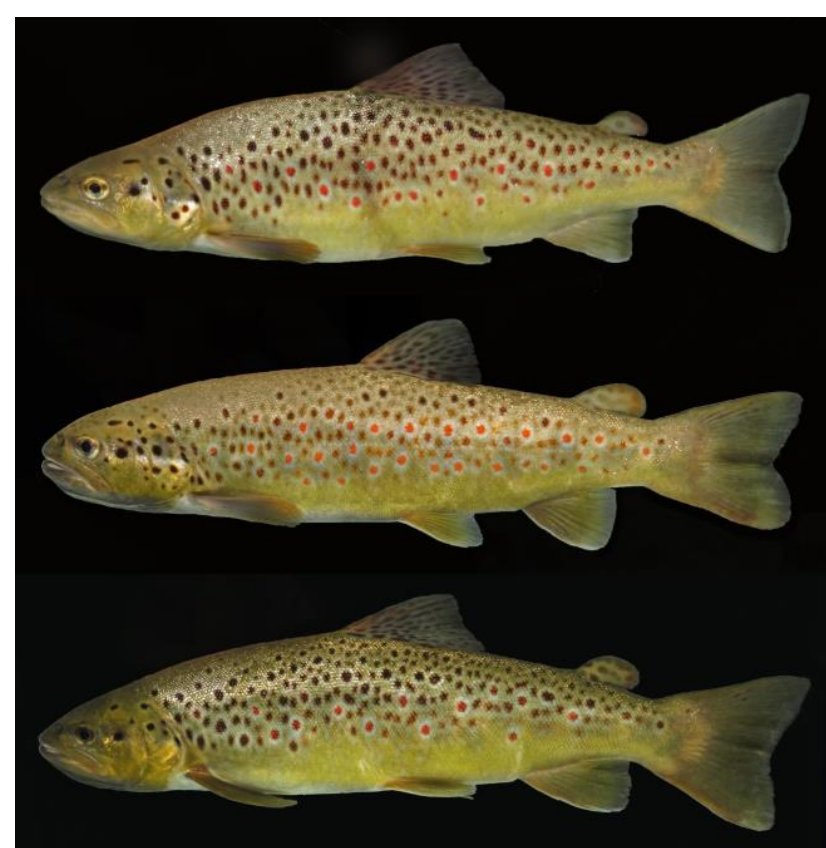

Figure 3. Salmo trutta, FFR 3238; from the top, $258 \mathrm{~mm} \mathrm{SL}$, male; 218 mm SL, female; 250 mm SL; Turkey, Bitlis Province, Stream Sapur, Lake Van drainage.

Native $S$. trutta is distributed from Norway to the Iberian Peninsula and Sicily, and upper Danube basin (Freyhof, 2011). Thus, the occurrence of the species in the eastern Anatolia zoogeographically is not predicted. The closest native range of the species is the upper Volga River in the north, and the upper Danube in the west (Freyhof, 2011). Therefore, it seems the species is translocated to the area.

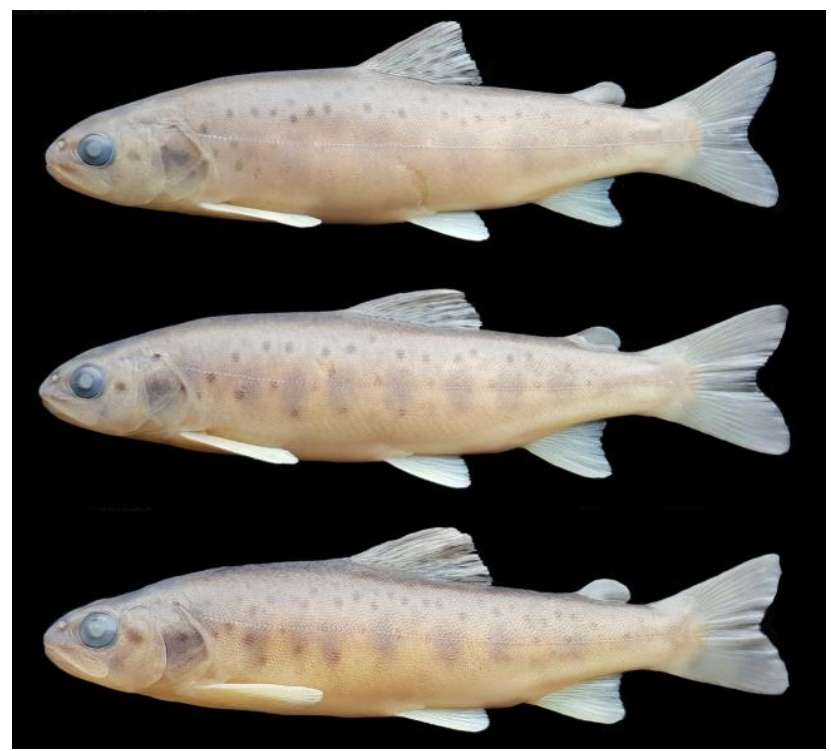

Figure 4. Salmo trutta, FFR 3237; juveniles, from the top, 114 $\mathrm{mm}$ SL, male; $115 \mathrm{~mm}$ SL, female; $97 \mathrm{~mm}$ SL; Turkey, Bitlis Province, Stream Arpet, Tigris catchment.

Towards the end of the 90s, some eyed eggs of Salmo trutta were transferred to Atatürk University (Erzurum) from France to test whether it can be used as a potential aquaculture species in Turkey (pers. comm. İlker
Zeki Kurtoğlu, 2020). Possibly some young individuals obtained from these eyed eggs of Salmo trutta were introduced to some proper habitats in eastern Anatolia. Probably most of them not successfully established, because we have never caught any $S$. trutta specimen during our many surveys in the last two decades in the area. However, the recent finding of $S$. trutta in stream Sapur and Arpet supports the reliability of the hypothesis which France origin S. trutta introduced in the eastern Anatolia.

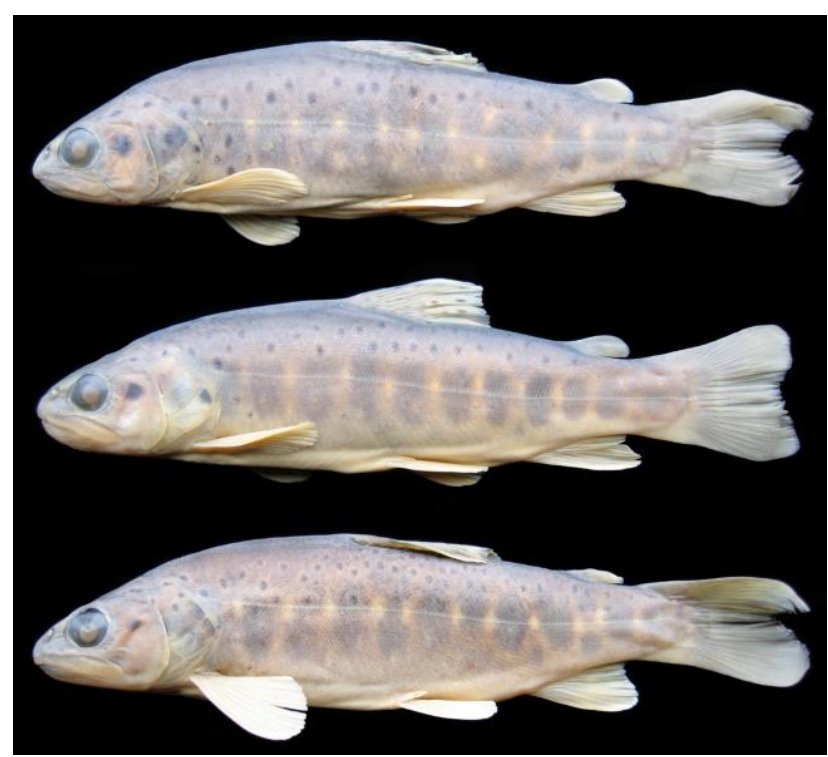

Figure 5. Salmo trutta, FSJF 1340, from top, $140 \mathrm{~mm} \mathrm{SL;} 138$ $\mathrm{mm}$ SL; $130 \mathrm{~mm}$ SL; Germany, Rhine River; Pleisbach Stream at Niederpleiss.

\section{DISCUSSION AND CONCLUSION}

Uncontrolled introducing fish in the waters inhabited by native species generally cause some critical problems. However, according to the first observation in the area, there is not a remarkable problem for streams Sapur and Arpet native species.

Barbus lacerta is the only native fish which occurs syntopic in stream Arpet with established S. trutta. The occurrence of the $S$. trutta in stream Arpet may affect the species negatively, however, $B$. lacerta is very widespread in entire Tigris-Euphrates catchments, and it was categorized as "Least Concern" by IUCN.

The endemic Alburnus tarichi is the only native fish in stream Sapur, and it could not reach even in the middle part of the stream (we observed the species up to 1 $\mathrm{km}$ upstream from the Lake). On the other hand, we did not observe any $S$. trutta specimen in the lower and middle parts of the stream during our several surveys in the area. The local anglers and the fish farm owners in the village confirmed the absence of the S. trutta in the lower and middle parts of the stream. The species was found only from the upper part of the stream (above from Küçüksu 
village, approximately $5 \mathrm{~km}$ upstream from the Lake). Moreover, we found many Oncorhynchus mykiss (rainbow trout) individuals escaped from a fish farm, about 25-40 $\mathrm{mm}$ SL, in the middle part of the stream (between approximately $1-3 \mathrm{~km}$ of the stream). Stream Sapur is sourced from a single spring and has comparatively cold water. Firstly, I thought that the lower part of the stream warmer, thus, A. tarichi could not reach the middle and upper part of the stream. However, Sanaç (2019) indicated that the temperature of the water is almost stable, and there are almost no differences between the upper and lower parts of the stream (average differences about $1{ }^{\circ} \mathrm{C}$, the upper part is colder). Thus, I consider that the temperature of the stream is not an obstacle for the A. tarichi to reach the middle and upper part of the stream. Probably, one of the obstacles is the occurrence of the carnivore $O$. mykiss after the first $\mathrm{km}$ of the stream. Because, when I started to find $O$. mykiss where $A$. tarich $i$ has not observed anymore. In this case, it can be suggested that $O$. mykiss may be an obstacle in the spawning migration of A. tarichi. On the other hand, it was reported that $A$. tarichi rarely enters to Stream Sapur, due to the pollution caused by the slaughterhouse in the area (Elp et al., 2014). Therefore, for the current status, I consider that introduction of the $S$. trutta in streams Sapur and Arpet is not a remarkable threat to the native fish species.

Freyhof et al. (2018) have been recently discussed the biogeographic connection of the endorheic Lake Van basin with the Tigris River. They found a very strong relationship, $0.2 \%$ minimum $\mathrm{K} 2 \mathrm{P}$ distance, between Alburnus timarensis (endemic to Lake Van basin) and $A$. kurui (endemic to Yüksekova wetland, upper Great Zap River, Tigris drainage). Moreover, Freyhof et al. (2019) concluded that the closest known relative of their newly described species Oxynoemacheilus muefiti (from the Murat River drainage) is O. ercisianus, with $1.8 \%$ minimum K2P distance. On the other hand, Barbus ercisianus and Capoeta kosswigi, thought to be endemic to the Van Lake basin, were considered as synonyms of $B$. lacerta and $C$. damascina in Tigris-Euphrates drainages, respectively (Khaefi et al., 2017, Kaya, 2019).

In the present study, I have realized that there is not a mountain or hill between the streams Sapur and Arpet. The distance between the uppermost part of the streams is just about $1 \mathrm{~km}$, and just 3 meters elevation is separate them. This means only 3 meters elevation separates the Lake Van basin and Tigris River also. This may explain the close relationship of the fishes of the Lake Van basin and Tigris-Euphrates river drainages. On the other hand, this proximity shows that Salmo trutta could have been easily translocated between the two streams.

In conclusion, the results of the current study show that the trout populations of streams Sapur and Arpet belong to translocated Salmo trutta which originated from France, and the occurrence of individuals of several sizes (85-325 $\mathrm{mm}$ SL), including juveniles (Figure 4), demonstrate that the species successfully established in these streams.

\section{Material Examined; \\ Material Used in Morphologic Comparisons: \\ Salmo trutta: FFR 03237, 21, 85-325 mm SL;}

Turkey: Bitlis Prov.: stream Arpet (Kocaçay) at Kokarsu, an uppermost drainage of Botan River, Tigris catchment, 38.3796, 42.2617.-FFR 03238, 20, 85-276 mm SL; Turkey: Bitlis Prov.: stream Sapur (Gökyokuş) at south of Tatvan, Lake Van drainage, 38.4496, 42.3782.-FSJF 1340, 17, 48-162 mm SL; Germany: Rhine River, Stream Pleisbach at Niederpleis, a tributary to River Sieg, 50.7447, 7.2403.

Material Used in Genetic Analysis:

S. fahrettini: Turkey, Erzurum, Ömertepesuyu Stream, Euphrates River drainage (GenBank accession number: MN815913; Turan et al., 2020).

S. tigridis: Turkey, Van, Çatak Stream, Tigris River drainage (GenBank accession number: MN815916; Turan et al., 2020).

S. munzuricus: Turkey, Tunceli, Munzur Stream, Euphrates River drainage (GenBank accession number: MN815914; Turan et al., 2020).

S. okumusi: Turkey, Sivas, Gökpinar Stream, Euphrates River drainage (GenBank accession number: MN815915; Turan et al., 2020).

S. euphrataeus: Turkey, Erzurum, Sirli Stream, Euphrates River drainage (GenBank accession number: MN815911; Turan et al., 2020).

S. trutta: Turkey, Van, Arpet Stream, Tigris River drainage (GenBank accession numbers: MT981164MT981165- MT981166- MT981167). -Turkey, Bitlis, Sapur Stream, Lake Van (GenBank accession numbers: MT981168- MT981169- MT981170- MT981171MT981172). -France, Corsica, Belle Bone (GenBank accession numbers: LT617531- LT617532- LT617533; Tougard et al., 2018). -France, Crequoise (GenBank accession number: LT617534; Tougard et al., 2018). France: Vidourle (GenBank accession number: LT617535; Tougard et al., 2018).

\section{ACKNOWLEDGEMENTS}

I would like to thank Cevdet Kaya, Safter Demir, Muammer Demir, Samet Demir, Vedat Ebem, and Muhammed Polat (Tatvan) for their help during the fieldwork. Many thanks to İsmail Aksu (Rize) for remarkable contributions on molecular, Davut Turan (Rize) on morphologic part of the study, and İlker Zeki Kurtoğlu (Rize) for his comments on the origin of Salmo trutta in Turkey. 


\section{REFERENCES}

Arıman, H. \& Kocaman, E.M. (2003). Aras, Yukarı Firat ve Çoruh Havzaları'nda yaşayan alabalık (Salmo trutta L.)'ların Atatürk Üniversitesi Ziraat Fakültesi Dergisi, 34, 193-197. [in Turkish].

Crête-Lafrenière, A., Weir, L.K. \& Bernatchez, L. (2012). Framing the Salmonidae family phylogenetic portrait: a more complete picture from increased taxon sampling. PLoS One, 7(10):e46662.

DOI:10.1371/journal.pone.0046662

Elp, M., Atici, A.A., Şen, F. \& Duyar, H.A. (2016). Distribution of fish species in the Van Lake basin. Yüzüncü Yıl Üniversitesi Tarım Bilimleri Dergisi, 26(4), 563-568.

Elp, M., Şen, F. \& Atici, A.A. (2014). İnci Kefalinin (Alburnus tarichi (Guldenstaedtii, 1814)) Van Gölü Havzası Su Kaynaklarındaki Yayılım Bölgeleri. Yüzüncü Yll Üniversitesi Tarım Bilimleri Dergisi, 24(3), 228-232. DOI: 10.29133/yyutbd.236277

Freyhof, J. (2011). Salmo trutta. The IUCN Red List of Threatened Species 2011: e.T19861A9050312. https://www.iucnredlist.org/species/19861/90503 12

Freyhof, J., Kaya, C., Turan, D. \& Geiger, M.F. (2019). Review of the Oxynoemacheilus tigris group with the description of two new species from the Euphrates drainage (Teleostei: Nemacheilidae). Zootaxa, 4612(1), 029-057. DOI: 10.11646/zootaxa.4612.1.2

Geldiay, R. \& Balık, S. (1999). Freshwater fishes of Turkey. Ege Üniversitesi Su Ürunleri Fakültesi Yayınları, No: 46, Ders Kitabı Dizini, No:16, Izmir, 519p. [in Turkish].

Hall, T.A. (1999). BioEdit: a user-friendly biological sequence alignment editor and analysis program for Windows 95/98/NT. Nucleic Acids Symposium Series, 41, 95-98

Kaya, C., Turan, D. \& Ünlü, E. (2016). The latest status and distribution of fishes in upper Tigris River and two new records for Turkish freshwaters. Turkish Journal of Fisheries and Aquatic Sciences, 16, 545-562. [in Turkish]. DOI: 10.4194/1303-2712v16_3_07.

Kaya, C. (2019). Türkiye'de dă̆llım gösteren Capoeta cinsine ait türlerin taksonomik revizyonu, $(\mathrm{PhD}$ dissertation). Recep Tayyip Erdogan University, Institute of Science and Technology, Rize, Turkey, 126p. [in Turkish].

Kelle, A., (1978). Dicle Nehri ve Kollarında Yaşayan Balıklar Üzerine Taksonomik ve Ekolojik Araştırmalar, (PhD dissertation). Diyarbakır Üniversitesi Tıp Fakültesi Biyoloji Kürsüsü, Diyarbakır, Turkey, 109p [in Turkish].

Khaefi, R., Esmaeili, H.R., Geiger, M.F. \& Eagderi, S. (2017). Taxonomic review of the cryptic Barbus lacerta species group with description of a new species (Teleostei: Cyprinidae). FishTaxa, 2(2), 90-115.
Kottelat, M. \& Freyhof, J. (2007). Handbook of European freshwater fishes. Publications Kottelat, Cornol, Switzerland. 646p.

Kumar, S., Stecher, G.G., Li, M., Knyaz, C. \& Tamura, K. (2018). MEGA X: molecular evolutionary genetics analysis across computing platforms. Molecular Biology and Evolution, 35, 1547-1549. DOI: 10.1093/molbev/msy096.

Kuru, M. (1975). Dicle-Fırat, Kura-Aras, Van Gölü Karadeniz Havzasi tatlisularında yaşayan balıkların (Pisces) sistematik ve zoocoğrafik yönden incelenmesi. Doçentlik Tezi, Atatürk Üniversitesi, Fen Fakültesi, Erzurum, 180p. [in Turkish].

Phillips, R., Matsuoka, M., Konon, I. \& Reed, K. (2000). Phylogenetic Analysis of Mitochondrial and Nuclear Sequences Supports Inclusion of Acantholingua ohridana in the Genus Salmo. Copeia, 2000(2), 546-550. www.jstor.org/stable/1448204. (5 August 2020).

Sanaç, R.R. (2019). Gökyokuş (Sapur) Deresi su kalite kriterleri üzerine bir araştırma, (Master dissertation). Van yüzüncü Yıl University, Institute of Science and Technology, Van, 74p. [in Turkish].

Sarı, H.M., Balık, S., Ustaoğlu, R. \& İlhan, A. (2006). Distribution and ecology of freshwater 1chthyofauna of the Biga Peninsula, Northwestern Anatolia, Turkey. Turkish Journal of Zoology, 30, 35-45.

Tamura, K. \& Nei, M. (1993). Estimation of the number of nucleotide substitutions in the control region of mitochondrial DNA in humans and chimpanzees. Molecular Biology and Evolution, 10(3), 512-26. DOI: 10.1093/oxfordjournals.molbev.a040023.

Thompson, J.D., Higgins, D.G. \& Gibson, T.J. (1994). CLUSTAL W: improving the sensitivity of progressive multiple sequence alignment through sequence weighting, position-specific gap penalties and weight matrix choice. Nucleic Acids Research, 22, 4673-4680.

Tougard, C, Justy, F, Guinand, B, Douzery, EJP, Berrebi, P. (2018). Salmo macrostigma (Teleostei, Salmonidae): Nothing more than a brown trout (S. trutta) lineage? Journal of Fish Biology, 93(2), 302-310. DOI: 10.1111/jfb.13751

Turan, D., Kottelat, M. \& Engin, S. (2010). Two new species of trouts, resident and migratory, sympatric in streams of northern Anatolia (Salmoniformes: Salmonidae). Ichthyological Exploration of Freshwaters, 20(4), (2009 [2010]), 289-384.

Turan, D., Kottelat, M. \& Bektaş, Y. (2011). Salmo tigridis, a new species of trout from Tigris River, Turkey (Teleostei: Salmonidae). Zootaxa, 2993, 23-33.

Turan, D., Kottelat, M. \& Engin, S. (2012). The trouts of the Mediterranean drainages of southern Anatolia, Turkey, with description of three new species (Teleostei: Salmonidae). Ichthyological Exploration of Freshwaters, 23, 219-236. 
Turan, D., Kottelat M. \& Engin, S. (2014a). Two new species of trouts from the Euphrates drainage, Turkey (Teleostei: Salmonidae). Ichthyological Exploration of Freshwaters, 24, 275-287.

Turan, D., Doğan, E., Kaya C. \& Kanyılmaz, M. (2014b). Salmo kottelati, a new species of trout from Alakır Stream, draining to the Mediterranean in southern Anatolia, Turkey (Teleostei, Salmonidae). Zookeys, 462, 135-151. DOI: $10.3897 /$ zookeys.462.8177.

Turan, D., Kottelat, M. \& Kaya, C. (2017). Salmo munzuricus, a new species of trout from the Euphrates River drainage, Turkey (Teleostei: Salmonidae). Ichthyological Exploration of Freshwaters, 28(1), 55-63.

Turan, D., Kalaycı, G., Bektaş, Y., Kaya, C. \& Bayçelebi, E. (2020). A new species of trout from the northern drainages of Euphrates River, Turkey (Salmoniformes: Salmonidae). Journal of Fish Biology, 1-9. DOI: 10.1111/jfb.14321.

Warheit, K.I. \& Bowman, C. (2008). Genetic structure of kokanee (Oncorhynchus nerka) spawning in tributaries of Lake Sammamish, Washington. Report to King County Department of Natural Resources and Parks, Water and Land Resources Division, and Trout UnlimitedBellevue/Issaquah, 50p. http://your.kingcounty. gov/dnrp/library/water-and-land/salmon/kokanee /warheit-genetics-report-062308.pdf. (01 July 2020). 